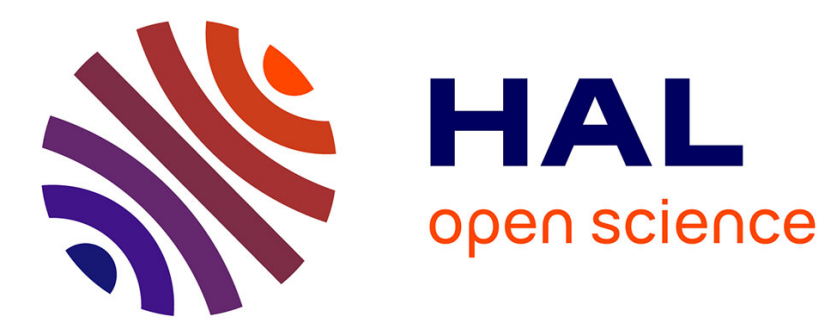

\title{
Species traits and habitats in springtail communities: a regional scale study
}

Sandrine Salmon, Jean-François Ponge

\section{To cite this version:}

Sandrine Salmon, Jean-François Ponge. Species traits and habitats in springtail communities: a regional scale study. Pedobiologia, 2012, 55 (6), pp.295-301. 10.1016/j.pedobi.2012.05.003 . hal00750242

\section{HAL Id: hal-00750242 \\ https://hal.science/hal-00750242}

Submitted on 9 Nov 2012

HAL is a multi-disciplinary open access archive for the deposit and dissemination of scientific research documents, whether they are published or not. The documents may come from teaching and research institutions in France or abroad, or from public or private research centers.
L'archive ouverte pluridisciplinaire HAL, est destinée au dépôt et à la diffusion de documents scientifiques de niveau recherche, publiés ou non, émanant des établissements d'enseignement et de recherche français ou étrangers, des laboratoires publics ou privés. 
1 Species traits and habitatsin springtail communities: a

2 regional scale study

3

4 S. Salmon,J.F. Ponge*

5

6 Muséum National d'Histoire Naturelle, CNRS UMR 7179, 4 avenue du Petit-Château,

791800 Brunoy France

8

$9 \quad$ Running title: Trait-habitat relationshipsin springtails

10

*Corresponding author. Tel.: +33 678930133.

E-mail address:ponge@mnhn.fr (J.F. Ponge). 


\section{Abstract}

2 Although much work has been done on factors patterning species trait assemblages in

3 emblematic groups such as plants and vertebrates, more remains to be done in

4 belowground invertebrate species. In particular,relationships between species traits and 5 habitat preferences are still a matter of debate. Springtails were sampled in a 6 heterogeneous landscape centered on the Sénart forest, near Paris (northern France), 7 embracingthe largest possible array of five environmental gradients (humus forms, 8 vegetation, moisture, vertical strata, and seasons) over which Collembola are known to 9 be distributed. Distances between samples varied from a few $\mathrm{cm}$ to several $\mathrm{km}$. Canonical correspondence analysis using species (128) as observations and species trait attributes (30) and habitat indicators (82) as dependent and independent variables, respectively, allowed to discern whether species habitats and species trait assemblages were related and which trends could be found in trait/environment relationships. It was concluded that, within the studied area, species habitatswere significantly associated with species trait assemblages. The main gradient explaining the distribution of species traits combined the vertical distribution of habitats (from the mineral soil to plant aerial parts), and the openness of the environment, i.e. a complex of many ecological factors. In the ecological traits of Collembola, this gradient corresponded to anincreasing contribution of sensory and locomotory organs, bright color patterns, size and sexual reproduction, all attributes associated with aboveground life under herbaceous cover. Another important, although secondarycontrast concerned traits associated with habitats far from soil but concealed (corticolous vs all other habitats). Soil acidity and water did not contribute significantly to trait distribution, at least within the limits of our database.

Keywords:Collembola; species trait assemblages; habitats; trait-environment relationships 
1

\section{Introduction}

The indicative power of species trait assemblages has been intensively studied in plants, birds and beetles and most species traits could be clearly related to habitat preferences of species in these groups (Graves and Gotelli 1993; Ribera et al. 2001;Cornwell and Ackerly 2009; Mayfield et al 2009; Pavoine et al. 2011). Surprisingly, although this is common sense and was reported for a long time in soil zoology (Bornebusch 1930), few studies questioned whether the extraordinary diversity of species traits which prevail in soil animal communities could be explained, and potentially could have been selected, by differences in habitat use (Vandewalle et al. 2010; Decaëns et al. 2011; Bokhorst et al. 2011).Moreover, these studies focused either on a restricted number of traits, or a restricted number of habitats which does not allow providing general trends in relationships between species traits and habitat use.

The aim of our study was to determine trends that emerge from traitenvironment relationships, i.e. how species traits vary along environmental gradients (e.g. vegetation, soil, depth).

Among soil invertebrates, we selected springtails (Hexapoda, Collembola) as an abundant and diversifiedmonophyletic group for which a great deal of work has been devoted to the study of species/environment relationships at the community level (Poole 1962; Hågvar 1982; Ponge 1993; Chagnon et al. 2000; Auclerc et al. 2009). The Sénart forest (Ile-de-France, northern France) and its vicinity were selected because they display a great variety of soil and soil-related habitats (e.g. woodland, heathland, grassland, ponds, paths, tree trunks) composing a little more than 3,000 ha of heterogeneous landscape, now totally included in the Paris area. Data collected from 1973 to 1977 , at a time when agriculture was still practiced both inside and outside the 
1 forest, were revisited for a statistical analysis taking into account species

2 trait/environment relationships. The same pool of data (370 samples, 127 species) has

3 been already used in several studies dealing with species/environment relationships

4 (Ponge 1980, 1983, 1993) and was included in the COLTRAIT data base

5 [http://www.bdd-inee.cnrs.fr/spip.php?article51\&lang=en], which also comprises data

6 about twelve morphological and life-history traits of more than 300 collembolan

7 species.

8 Materials and Methods

9 Site description

The Sénart state forest $(3,000 \mathrm{ha})$ is located $20 \mathrm{~km}$ south-east of Paris on the western border of the Brie plateau, delineated by a meander of river Seine and by a tributary, the river Yerres, at an altitude ranging from 50 to $87 \mathrm{~m}$ a.s.l. At the time of sampling it was mainly bordered by urbanized areas (communes of Quincy-sous-Sénart, Boussy-Saint-Antoine, Brunoy, Yerres, Montgeron, Draveil) on its western and northern parts, and by agricultural areas (communes of Soisy, Étiolles, Tigery, Lieusaint, Combs-la-Ville) on its eastern and southern parts. Nowadays, the forest is totally included in the metropolitan area of Paris. Private peripheral woods and agricultural areas (cultures and meadows) were included in the study. Most of them have now been incorporated into the state forest, to the exception of peripheral agricultural areas which have been built or transformed into golf courses or other recreational areas.A number of soil types can be observed in the Sénart forest, varying according to the nature of quaternary deposits (loess or gravels) and permanent or seasonal waterlogging resulting from clay migration (perched water tables) or 
1

2

3

4

5

6

underlying impervious clay strata (permanent water tables). More details were given in previously published papers (Ponge 1980, 1983, 1993).

\section{Sampling procedure}

Sampling took place from $15^{\text {th }}$ October 1973 to $10^{\text {th }}$ October 1977 in every season and every kind of weather, our purpose being to embrace all climate conditions, except when the soil was deeply frozen and could not be sampled at all. At each sampling time, a point was randomly selected, around which all visible sitespotentially available to springtails were investigated, from deep soil (leached mineral horizons) to tree trunks two meters aboveground and to floating vegetation in water-filled ponds. No effort was made to standardize sampling, the only requirement being to collect enough litter (at all stages of decomposition), vegetation (aerial and subterranean parts), bark (naked or covered with lichens or mosses) or soil (organo-mineral to mineral horizons) to have enough animals as possible in each sample, the aim of the study being to know which species were living together in the same micro-habitat and which species were not.The volume sampled varied from $100 \mathrm{~mL}$ for moss cushions, which are particularly rich in springtails (Gerson 1982) to $1 \mathrm{~L}$ for bleached mineral soil horizons which are strongly impoverished in fauna (Hågvar 1983). Care was taken not to undersample some poorly represented habitats. For that purpose some additional sampling was done in agricultural areas, calcareous soils and dumping places. This procedure allows environmental gradients to be better described (Gillison and Liswanti 2004).

Samples were taken with the help of a shovel for soil, and with fingersfor aboveground samples, care being taken not to lose too many jumping animals in particular when sampling aerial parts of erected plants. No attempt was done to force a corer into the soil. Samples were immediately put in plastic bags then transported to the nearby 
1 laboratory, to be extracted on the same day. Extraction was done by the dry funnel

2 (Berlese) method over 10 days, using $25 \mathrm{~W}$ bulb lamps in order to avoid too rapid

3 desiccation of the samples, known to prevent slowly moving animals from escaping

4 actively the samples (Nef 1960). Animals were collected and preserved in $95 \%$ ethyl

5 alcohol in plastic jars. A total of 310 samples were collected and kept for the analysis.

6 Species identification

Animals were sorted in Petri dishes filled with ethyl alcohol then springtails were mounted and cleared in chloral-lactophenol to be identified under a light microscope at x 400 magnification. At the time of study the only key available for European springtails was that of Gisin (1960), to which were added numerous detailed published studies at family, genus or species level (complete list available upon request), and miscellaneous (unpublished) additions by Gisin himself. Color patterns were noted before animals were discolored in chloral-lactophenol. Young specimens, when not identifiable to species level, were allocated to known species by reference to adults or subadults found in the same sample, or in samples taken in the vicinity. For instance in the genus Mesaphorura, where several species may cohabit and diagnostic characters are not revealed in the first instar (Rusek 1980), unidentified juveniles were proportionally assigned to species on the base of identified specimens found in the same sample. Gisin's nomenclature was updated using Fauna Europaea 2011 [http://www.faunaeur.org/]. A total of 128 species were found (Table 1).

Trait data

Twelve traits, mostly extracted from the COLTRAIT data base and collected from numerous identification keys or synopses, describe morphology and reproductive mode of the 128 species used in the analysis. Attributes of each trait (Table 3) were 
1 considered as variables, and were coded as binary (dummy) variables, resulting in a list

2 of 30 attributes: mode of reproduction (parthenogenesis dominant, sexual reproduction

3 dominant), body size (small, medium, large), body form (cylindrical body, stocky body,

4 spherical body), body color (pale-colored, bright-colored, dark-colored), scales (absent,

5 present), antenna size (short, long), leg size (short, long), furcula size (absent or

6 vestigial, short, long), eyenumber $(0,1-5,>5)$, pseudocella (absent, present), post-

7 antennal organ (absent, simple, compound), and trichobothria (absent, present).

8 Antennae, eyes, post-antennal organsand trichobothria are supposed to play a sensory

9 role (Hopkin 1997).

Species habitat data

Field notes were used to classify habitat features (sensu lato, including microhabitat and season) in 82 categories (Table 2). To each sample was thus assigned a set of 82 habitat indicators which describe its main features at varying scales, from landuse (heathland, grassland, woodland) to sampling plot (e.g. ditch, plain ground, pond, vegetation, soil $\mathrm{pH}$ ) then to within-plot scale (e.g. plant part, litter, earthworm casts, mineral soil). Species presence was indicated by dummy variables (coded as 0 or 1 ) for each of the 82 habitat categories.

Statistical treatment of the data

Canonical correspondence analysis was used to analyze trait-habitat relationships (species as observations, species trait attributes as dependent variables, species habitatsas constraining variables), permutation tests being used to test traithabitat associations.

Rarefaction curves were calculated to estimate the exhaustiveness of our sampling method.Rarefaction curves and jacknife estimators were calculated using 
1 EstimateS (version 8.2.0).All other calculations were done using XLSTAT $^{\circledR}$

2 (Addinsoft $^{\circledR}$, Paris, France).

\section{Results}

The rarefaction curve of the 128 observed species showed that sampling had approached an asymptote. Estimating the number of missing species according to Chao (1987) put the expected total number of species for the Sénart forest to 133 and indicated that the sampling was relatively exhaustive.

Canonical Correspondence Analysis (CCA)with species trait attributes as explained variables and species habitats as explanatory variables showed that traits were significantly explained by habitats (number or permutations $=500$, pseudo- $\mathrm{F}=0.94, \mathrm{P}<$ 0.0001). Constrained variance (variance of species traits explained by species habitats) represented $72.9 \%$ of the total variance.

The first two canonical components of CCA extracted $54 \%$ of the constrained (explained) variance ( $40 \%$ and $14 \%$ for $\mathrm{F} 1$ and $\mathrm{F} 2$, respectively). The projection of trait attributes and species in the F1-F2 plane is shown in Figures 1a and 1b, respectively. Both species and trait attributes were distributed along three dimensions. Species with pseudocella and post-antennal organ present (of compound type), parthenogenesis dominant, regressed locomotory (furcula, legs) and sensorial organs (eyes, antennae, thichobothria), and pale color were opposed to species displaying opposite attributes along F1. According to principal coordinates of species habitats (Table 2) this corresponded to opposite habitats: woodland vs grasslandand depth versus surface, from negative to positive sides of F1. Heathland was in an intermediate position between woodland and grassland (Table 2). Mineral soil, organo-mineral soil, humus (organic), litter, plant aerial parts ranked in this order along F1. Sunlight was projected on the 
1 positive side of F1 (open environments). The second canonical component F2 was more

2 specifically linked to corticolous microhabitats (trunks, wood and associated mosses

3 and lichens): associated trait attributes were short furcula, stocky and dark-colored

4 body, eyes present but in regressed number (1-5), post-antennal organ present but

5 simple. Acidity and humus type, as well as water, did not exhibit any pronounced

6 influence on species trait attributes. Partial CCA, allowing only water and soil acidity

7 (including humus type) to vary, showed that they did not influence the distribution of

$8 \quad$ trait attributes (pseudo-F $=0.17, \mathrm{P}=0.99$ ).

\section{Discussion}

Previous studies showed that a limited number of ecological factors could explain the distribution of collembolan species when collected in the same geographical context, at a regional scale (Ponge 1993; Ponge et al. 2003). Vertical distribution is the main gradient along which most springtail species are distributed (Hågvar 1983; Faber and Joosse1993; Ponge 2000a), followed by the contrast between woodland and grassland (Ponge et al. 2003), and other factors such as water availability (Verhoef and Van Selm 1983) and soil acidity (Loranger et al. 2001). We showed that grassland and epigeic habitats were mostly characterized by traits adapting species to surface life: big size, high mobility, protection against desiccation by round shape or cuticular clothing (Kaersgaard et al. 2004), avoidance of predation by flight and color signaling, and sexual reproduction (Fig. 1, Table 2, F1 component, positive side). On the oppositeside, woodland and endogeic habitats were mostly characterized by traits associated with subterranean life: small size, small locomotory appendages, poor protection from desiccation, avoidance of predation by toxic excreta (pseudocella), and parthenogenesis. 
Much life in woodland is more concealed than in grassland: smaller forms, more sensitive to environmental stress because of a higher surface/volume ratio (Kærsgaard et al. 2004;Bokhorst et al. 2012), and less motile species (Auclerc et al. 2009), can find in woodland better conditions for survival and reproduction. Mebes and Filser (1997) showed that surface dispersal of Collembola was much more intense in agricultural fields compared to adjoining shrubby fallows where litter began to accumulate, and Alvarez et al. (1997, 2000) highlighted the role of hedgerows as temporary refuges for species living at the surface of arable fields. Sexual reproduction needs easy-to-visit sites for the deposition of spermatophores by males (Chahartaghi et al. 2006), and movement in search of mating partners using olfactory or tactile clues (Chernova et al. 2010), which is easier in surface than in depth, in the same sense as escape from predators needs visual or tactile sensory organs to detect their presence (Baatrup et al. 2006) and needs jumping movements (ensured by furcula acting as a spring) for fleeing away (Bauer and Christian 1987). The fractionation of space within leaf or needle litter horizons makes the forest floor improper to rapid surface movements (Bauer and Christian 1987), while protecting soil-dwelling animals from surface predation by carabids and vertebrates (Hossie and Murray 2010) and offering a variety of food resources such as fungal colonies and animal excreta (Bengtsson et al. 1991; Salmon and Ponge 2001). Other predators are subterranean and cannot be avoided through active movements, hence the use of chemical repellents excreted by pseudocella (Dettner et al. 1996; Negri 2004).

Despite clear trends of trait/habitat relationships exhibited by our results, possible biases due to escape movements during sampling, in particular from the part of big-size animals with long furcula, should not be overlooked. If such biases differ from a habitat to another, this may flaw trait/habitat relationships. However, concerning the 
association between big size and agricultural environments, which is novel to science, it must be highlighted that it was less easy to collect vary motile specimens in the absence of litter (i.e. in agricultural areas) than when litter was present (i.e. in forest areas), stemming in a bias in quite opposite direction to the observed association. This made us confident that such biases were not present in our dataset.

The second canonical component of trait-environment relationships (Fig. 1, Table 2, F2 component) distinguishes traits associated with life in bark and associated mosses and lichens: the combination of short furcula, dark color, stocky body, eyes present but in limited number is an original adaptation to life in concealed environments (hence small size and limited movements) but far from soil (hence the need to be protected from UV radiation through pigmentation and possibilities offered by vision). The structure of the post-antennal organ, opposing simple to compound structure (more typical of edaphic habitat) is worthy of note, since no other studies considered its ecological correlates. The exact role played by this organ is still unknown, but anatomical observations on the innervation of these pitted porous plates located not far from the protocerebrum point to sensory activity (Altner and Thies 1976). Differences between simple and compound post-antennal organs concern the number of dendritic branches, which are more numerous in compound organs (Altner and Thies 1976), suggesting that compound post-antennal organs are more sensitive to chemical features of the immediate environment. The higher sensitivity of the compound post-antennal organ could be more adapted to deeper horizons by compensating the reduction or the complete absence of other sense organs such as eyes.

The fact that we did not discern any association between traits and obvious factors such as water and soil acidity (or humus type) does not preclude any further scrutiny of such relationships. Two reasons could be invoked.First, that, in its present 
1 state, our database did not cover the traits needed to establish this relationship. Ponge

2 (2000b) showed that acidophilic and acidophobic species cohabited within the same

3 lineage, pointing to corresponding traits as mainly based on physiology (mechanisms

4 counteracting oxidative stress) rather than on anatomy and reproduction mode. Traits

5 associated with aquatic life concern mainly the form and size of claws (Gisin 1960), and

6 of course physiology (resistance to desiccation), which were not considered here.

7 Second, in the particular case of the Senart forest, traits adapting species to habitats

8 varying in terms of water availability and/or soil acidity could be masked by landuse or

9 vertical stratification effects, pointing to the need for studying trait/habitat relationships

10 on a wider geographic scale, as suggested by Lepetz et al. (2009).

\section{References}

12 Altner, H., Thies,G., 1976. The post-antennal organ: a specialized unicellular sensory input to the protocerebrum in apterygotan insects (Collembola). Cell Tissue Res. $167,97-110$.

Alvarez, T., Frampton, G.K., Coulson,D., 1997. Population dynamics of epigeic Collembola in arable fields: the importance of hedgerow proximity and crop type. Pedobiologia 41, 110-114.

Alvarez, T., Frampton, G.K., Coulson,D., 2000.The role of hedgerows in the recolonisation of arable fields by epigeal Collembola.Pedobiologia 44, 516-526.

Auclerc, A., Ponge, J.F., Barot, S., Dubs,F., 2009. Experimental assessment of habitat preference and dispersal ability of soil springtails. Soil Biol. Biochem. 41, 15961604. 
1 Baatrup, E., Bayley, M.,Axelsen,J.A., 2006.Predation of the mite Hypoaspisaculeifer on the springtail Folsomia fimetaria and the influence of sex, size, starvation, and poisoning.Entomol. Exp. Appl. 118, 61-70.

Bauer, T., Christian,E., 1987.Habitat dependent differences in the flight behavior of Collembola.Pedobiologia 30, 233-239.

Bengtsson, G., Hedlund, K., Rundgren, S., 1991. Selective odor perception in the soil Collembola Onychiurusarmatus.J. Chem. Ecol. 17, 2113-2125.

Bokhorst, S., Phoenix, G.K., Bjerke, J.W., Callaghan, T.V., Huyer-Brugman, F., Berg, M.P., 2012. Extreme winter warming events more negatively impact small rather than large soil fauna: shift in community composition explained by traits not taxa. Glob. Change Biol 18, 1152-1162.

Bornebusch, C.H.,1930. The fauna of forest soil.Forstl.Forsøksv.Danmark11, 1-158.

Chagnon, M., Hébert, C., Paré, D., 2000.Community structures of Collembola in sugar maple forests: relations to humus type and seasonal trends. Pedobiologia 44, 148-174.

Chahartaghi, M., Scheu, S.,Ruess,L., 2006.Sex ratio and mode of reproduction in Collembola of an oak-beech forest.Pedobiologia 50, 331-340.

Chao, A., 1987. Estimating the population size for capture-recapture data with unequal catchability. Biometrics 43, 783-791.

Chernova, N.M., Potapov, M.B., Savenkova, Y.Y.,Bokova,A.I., 2010.Ecological significance of parthenogenesis in Collembola.Entomol. Rev. 90, 23-38. 
1 Cornwell, W.K., Ackerly, D.D., 2009. Community assembly and shifts in plant trait distributions across an environmental gradient in coastal California. Ecol. Monogr. 79, 109-126.

Decaëns, T., Margerie P., Renault, J., Bureau, F., Aubert, M., Hedde, M., 2011. Niche overlap and species assemblage dynamics in an ageing pasture gradient in northwestern France. ActaOecol. 37, 212-219.

Dettner, K., Scheuerlein, A.,Fabian, P.,Schulz, S.,Francke,W., 1996. Chemical defense of giant springtail Tetrodontophorabielanensis (Waga) (Insecta: Collembola). J. Chem. Ecol. 22, 1051-1074.

Faber, J.H., Joosse,E.N.G., 1993. Vertical distribution of Collembola in a Pinus nigra organic soil.Pedobiologia 37, 336-350.

Gerson, U., 1982. Bryophytes and invertebrates.In:Smith, A.J.E. (Ed.), Bryophyte Ecology Chapman and Hall, London, pp. 291-332.

Gillison, A.N., Liswanti,N., 2004. Assessing biodiversity at landscape level in northern Thailand and Sumatra (Indonesia): the importance of environmental context.Agr. Ecosyst. Environ. 104, 75-86.

Gisin, H., 1960. CollembolenfaunaEuropas. Muséum d'Histoire Naturelle, Geneva.

Graves, G.R., Gotelli, N.J., 1993.Assembly of avian mixed-species flocks in Amazonia. P. Natl Acad. Sci. USA 90, 1388-1391.

Hågvar, S., 1982.Collembola in Norwegian coniferous forest soils. I. Relations to plant communities and soil fertility. Pedobiologia 24, 255-296. 
1 Hågvar, S., 1983.Collembola in Norwegian coniferous forest soils. II. Vertical distribution. Pedobiologia 25, 383-401.

Hopkin, S.P., 1997. Biology of the Springtails (Insecta: Collembola). Oxford University Press, Oxford.

Hossie, T.J., Murray, D.L., 2010. You can't run but you can hide: refuge use in frog tadpoles elicits density-dependent predation by dragonfly larvae. Oecologia 163, 395-404.

Kærsgaard, C.W., Holmstrup, M.,Malte, H., Bayley,M.,2004.The importance of cuticular permeability, osmolyte production and body size for the desiccation resistance of nine species of Collembola. J. Insect Physiol. 50, 5-15.

Lepetz, V., Massot, M., Schmeller, D.S., Clobert, J., 2009. Biodiversity monitoring: some proposals to adequately study species' responses to climate change. Biodivers.Conserv. 18, 3185-3203.

Loranger, G., Bandyopadhyaya, I., Razaka, B., Ponge,J.F., 2001. Does soil acidity explain altitudinal sequences in collembolan communities? Soil Biol. Biochem. $33,381-393$.

Mayfield, M.M., Boni, M.F., Ackerly, D.D., 2009. Traits, habitats, and clades: identifying traits of potential importance to environmental filtering. Am. Nat. 174, E1-E22.

Mebes, K.H.,Filser,J., 1997. A method for estimating the significance of surface dispersal for population fluctuations of Collembola in arable land.Pedobiologia 41, 115-122. 
1 Nef, L., 1960. Comparaison de l'efficacité de différentes variantes de l'appareil de Berlese-Tullgren. Z. Angew. Entomol. 46, 178-199.

Negri, I., 2004. Spatial distribution of Collembola in presence and absence of a predator.Pedobiologia 48, 585-588.

Pavoine, S., Vela, E.,Gachet, S.,de Bélair, G.,Bonsall,M.B.,2011. Linking patterns in phylogeny, traits, abiotic variables and space: a novel approach to linking environmental filtering and plant community assembly.J. Ecol. 99, 165-175.

Ponge, J.F., 1980. Les biocénoses des collemboles de la forêt de Sénart. In Pesson, P. (Ed.),Actualités d'Écologie Forestière.Gauthier-Villars, Paris, pp. 151-176.

Ponge, J.F., 1983. Les collemboles, indicateurs du type d'humus en milieu forestier: résultats obtenus au sud de Paris. ActaOecol.Oec. Gen. 4, 359-374.

Ponge, J.F., 1993. Biocenoses of Collembola in atlantic temperate grass-woodland ecosystems. Pedobiologia 37, 223-244.

Ponge, J.F., 2000a. Vertical distribution of Collembola (Hexapoda) and their food resources in organic horizons of beech forests. Biol. Fert. Soils 32, 508-522.

Ponge, J.F., 2000b. Acidophilic Collembola: living fossils? Contr. Biol. Lab. Kyoto Univ. 29, 65-74.

Ponge, J.F., Gillet, S., Dubs, F., Fedoroff, E., Haese, L., Sousa, J.P. Lavelle, P., 2003. Collembolan communities as bioindicators of land use intensification. Soil Biol. Biochem. 35, 813-826. 
1 Poole, T.B., 1962. The effect of some environmental factors on the pattern of distribution of soil Collembola in a coniferous woodland. Pedobiologia 2, 169182.

Ribera, I., Doledec, S.,Downie, I.S. Foster,G.N.,2001.Effect of land disturbance and stress on species traits of ground beetle assemblages. Ecology 82, 1112-1129.

Rusek, J., 1980. Morphology of juvenile instars in two Mesaphoruraspecies (Collembola: Tullbergiinae). Rev. Ecol. Biol. Sol17, 583-589.

Salmon, S., Ponge,J.F., 2001. Earthworm excreta attract soil springtails: laboratory experiments on Heteromurus nitidus (Collembola: Entomobryidae). Soil Biol. Biochem. 33, 1959-1969.

Vandewalle, M., de Bello, F.,Berg, M.P.,Bolger, T.,Dolédec, S.,Dubs, F.,Feld, C.K.,Harrington, R.,Harrison, P.A.,Lavorel, S.,da Silva, P.M., Moretti, M., Niemelä, J., Santos, P., Sattler, T., Sousa, J.P., Sykes, M.T., Vanbergen, A.J., Woodcock,B.A., 2010. Functional traits as indicators of biodiversity response to land use changes across ecosystems and organisms. Biodivers.Conserv. 19, 2921-2947.

Verhoef, H.A., Van Selm,A.J., 1983. Distribution and population dynamics of Collembola in relation to soil moisture.Holarctic. Ecol. 6, 387-394. 
Table 1. Codes and species names of springtails collected in the Senart forest from 1973 to 1977 , total abundance, and number of samples in which the species was found. Species names according to Fauna Europaea 2011

\begin{tabular}{|c|c|c|c|c|c|c|c|}
\hline Code & Species name & Abundance & $\begin{array}{l}\text { Number of } \\
\text { samples }\end{array}$ & Code & Species name & Abundance & $\begin{array}{c}\text { Number of } \\
\text { samples }\end{array}$ \\
\hline$\overline{\mathrm{ACA}}$ & Arrhopalites caecus & 23 & 6 & MKR & Mesaphorura krausbaueri & 813 & 69 \\
\hline $\mathrm{AEL}$ & Anurida ellipsoides & 12 & 4 & MMA & Mesaphorura macrochaeta & 2962 & 102 \\
\hline AFU & Allacma fusca & 1 & 1 & MMI & Megalothorax minimus & 963 & 105 \\
\hline AGA & Allacma gallica & 5 & 2 & MMS & Mesaphorura massoudi & 31 & 2 \\
\hline APR & Arrhopalites principalis & 9 & 7 & MMT & Micronychiurus minutus & 1 & 1 \\
\hline APY & Arrhopalites pygmaeus & 13 & 7 & MMU & Micranurophorus musci & 5 & 1 \\
\hline ASE & Arrhopalites sericus & 24 & 8 & MPY & Micranurida pygmaea & 829 & 72 \\
\hline BPA & Brachystomella parvula & 1036 & 33 & MSE & Micranurida sensillata & 2 & 2 \\
\hline BVI & Bourletiella viridescens & 50 & 15 & MYO & Mesaphorura yosii & 158 & 13 \\
\hline CAL & Cyphoderus albinus & 3 & 2 & NDU & Neonaphorura duboscqi & 2 & 1 \\
\hline CBE & Ceratophysella bengtssoni & 436 & 4 & NMU & Neanura muscorum & 115 & 53 \\
\hline $\mathrm{CBI}$ & Cryptopygus bipunctatus & 2 & 1 & NNO & Neonaphorura novemspina & 1 & 1 \\
\hline CDE & Ceratophysella denticulata & 117 & 16 & NRA & Neotullbergia ramicuspis & 28 & 2 \\
\hline CEX & Cryptopygus exilis & 4 & 3 & OAM & Onychiurus ambulans & 2 & 2 \\
\hline CMA & Caprainea marginata & 9 & 2 & $\mathrm{OCl}$ & Orchesella cincta & 1460 & 81 \\
\hline csc & Cryptopygus scapelliferus & 22 & 3 & OCR & Oncopodura crassicornis & 5 & 3 \\
\hline СТH & Cryptopygus thermophilus & 13 & 2 & OPS & Onychiuroides pseudogranulosus & 347 & 13 \\
\hline DFL & Deuterosminthurus flans & 7 & 5 & OVI & Orchesella villosa & 167 & 44 \\
\hline DFI & Deuteraphorura fimetaria & 1 & 1 & PAL & Pseudosinella alba & 279 & 51 \\
\hline DFU & Dicyrtoma fusca & 34 & 19 & $P A Q$ & Podura aquatica & 410 & 7 \\
\hline DJU & Detriturus jubilarius & 1 & 1 & PAS & Pseudachorutella asigillata & 16 & 5 \\
\hline DMI & Dicyrtomina minuta & 56 & 30 & PAU & Protaphorura aurantiaca & 740 & 24 \\
\hline DTI & Desoria tigrina & 1192 & 5 & PCA & Paratullbergia callipygos & 430 & 53 \\
\hline EAL & Entomobrya albocincta & 120 & 17 & PDE & Pseudosinella decipiens & 7 & 6 \\
\hline ELA & Entomobrya lanuginosa & 39 & 13 & PLO & Pogonognathellus longicornis & 7 & 5 \\
\hline EMA & Entomobrya multifasciata & 166 & 11 & PMA & Pseudosinella mauli & 430 & 48 \\
\hline EMU & Entomobrya muscorum & 17 & 15 & PMI & Proisotoma minima & 156 & 25 \\
\hline ENI & Entomobrya nivalis & 74 & 8 & PMU & Proisotoma minuta & 212 & 10 \\
\hline EPU & Entomobryoides purpurascens & 11 & 2 & PNO & Parisotoma notabilis & 6095 & 180 \\
\hline FCA & Folsomia candida & 60 & 9 & PPA & Pseudachorutes parvulus & 229 & 35 \\
\hline FCL & Friesea claviseta & 67 & 11 & PPE & Pseudosinella petterseni & 1 & 1 \\
\hline FMA & Folsomia manolachei & 6274 & 101 & PPO & Pseudosinella pongei & 12 & 4 \\
\hline FMI & Friesea mirabilis & 109 & 13 & PSE & Pseudisotoma sensibilis & 1464 & 12 \\
\hline FPA & Folsomides parvulus & 145 & 13 & PSU & Protaphorura subuliginata & 193 & 20 \\
\hline FQU & Folsomia quadrioculata & 1810 & 45 & $S A Q$ & Sminthurides aquaticus & 1 & 1 \\
\hline FQS & Fasciosminthurus quinquefasciatus & 2 & 2 & SAS & Sminthurides assimilis & 78 & 12 \\
\hline FTR & Friesea truncata & 361 & 57 & SAU & Sminthurinus aureus aureus & 1054 & 75 \\
\hline GFL & Gisinianus flammeolus & 98 & 6 & SDE & Stenaphorurella denisi & 32 & 5 \\
\hline $\mathrm{HCL}$ & Heterosminthurus claviger & 3 & 1 & SEL & Sminthurinus elegans & 95 & 21 \\
\hline HIN & Heterosminthurus insignis & 33 & 7 & SLA & Superodontella lamellifera & 4 & 3 \\
\hline HMA & Heteromurus major & 594 & 71 & SMA & Sminthurides malmgreni & 591 & 43 \\
\hline $\mathrm{HNI}$ & Heteromurus nitidus & 28 & 18 & SNI & Sminthurus nigromaculatus & 16 & 9 \\
\hline HPU & Hypogastrura purpurescens & 1 & 1 & SPA & Sminthurides parvulus & 82 & 13 \\
\hline IAN & Isotomurus antennalis & 1 & 1 & SPS & Subisotoma pusilla & 82 & 5 \\
\hline IMI & Isotomiella minor & 2136 & 116 & SPU & Sphaeridia pumilis & 1566 & 107 \\
\hline IPA & Isotomurus palustris & 1483 & 101 & SQU & Stenaphorurella quadrispina & 7 & 3 \\
\hline IPR & Isotomodes productus & 4 & 1 & SSC & Sminthurides schoetti & 401 & 44 \\
\hline ISP & Isotomodes sp. & 2 & 2 & SSE & Schaefferia sexoculata & 1 & 1 \\
\hline IVI & Isotoma viridis & 54 & 13 & SSI & Sminthurinus aureus signatus & 2407 & 97 \\
\hline KBU & Kalaphorura burmeisteri & 30 & 5 & STR & Sminthurinus reticulatus & 1 & 1 \\
\hline LCU & Lepidocyrtus curvicollis & 72 & 26 & SVI & Stenacidia violacea & 6 & 2 \\
\hline LCY & Lepidocyrtus cyaneus & 889 & 35 & TBO & Tomocerus botanicus & 35 & 9 \\
\hline LLA & Lepidocyrtus lanuginosus & 3399 & 160 & TMI & Tomocerus minor & 312 & 45 \\
\hline LLI & Lepidocyrtus lignorum & 565 & 63 & VAR & Vertagopus arboreus & 788 & 31 \\
\hline LLU & Lipothrix lubbocki & 15 & 6 & WAN & Willemia anophthalma & 577 & 35 \\
\hline LPA & Lepidocyrtus paradoxus & 2 & 2 & WBU & Willemia buddenbrocki & 5 & 3 \\
\hline LVI & Lepidocyrtus violaceus & 4 & 4 & WIN & Willemia intermedia & 1 & 1 \\
\hline$M A B$ & Micraphorura absoloni & 3 & 2 & WNI & Willowsia nigromaculata & 3 & 1 \\
\hline MBE & Mesaphorura betschi & 12 & 6 & WPO & Wankeliella pongei & 2 & 1 \\
\hline MGR & Monobella grassei & 32 & 14 & $\mathrm{XBR}$ & Xenylla brevisimilis & 2 & 1 \\
\hline MHG & Mesaphorura hygrophila & 1 & 1 & XGR & Xenylla grisea & 361 & 19 \\
\hline MHY & Mesaphorura hylophila & 633 & 42 & XSC & Xenylla schillei & 18 & 5 \\
\hline MIN & Megalothorax incertus & 12 & 9 & XTU & Xenylla tullbergi & 4673 & 68 \\
\hline MIT & Mesaphorura italica & 21 & 9 & XXA & Xenylla xavieri & 33 & 5 \\
\hline
\end{tabular}


Table 2. Habitat indicators, number of samples where indicators were quoted as 1 and principal coordinates along the two first components of CCA. F1 component ( $40 \%$ of explained variance) is linked to landuse and depth. F2 component (14\% of explained variance) is linked more specifically to corticolous micro-habitats

\begin{tabular}{|c|c|c|c|c|c|c|c|}
\hline & $\begin{array}{c}\text { Number of } \\
\text { samples }\end{array}$ & $\mathbf{F 1}$ & F2 & & $\begin{array}{c}\text { Number of } \\
\text { samples }\end{array}$ & $\mathbf{F 1}$ & F2 \\
\hline Autumn & 96 & 0.045 & 0.084 & Hornbeam & 42 & -0.046 & 0.037 \\
\hline Winter & 108 & 0.162 & 0.051 & Linden & 22 & -0.012 & 0.001 \\
\hline Spring & 88 & 0.091 & 0.035 & Maple & 8 & 0.053 & 0.049 \\
\hline Summer & 46 & 0.109 & 0.030 & Ash & 8 & 0.011 & 0.026 \\
\hline Grassland & 50 & 0.136 & -0.021 & Cherry & 9 & 0.097 & -0.066 \\
\hline Woodland & 279 & -0.124 & 0.006 & Elm & 3 & 0.170 & 0.057 \\
\hline Heathland & 9 & 0.064 & 0.029 & Elder & 3 & 0.112 & -0.012 \\
\hline Ditch/brook & 44 & 0.106 & 0.059 & Hazel & 11 & -0.027 & -0.040 \\
\hline Pond & 64 & 0.140 & 0.056 & Pine & 12 & 0.007 & 0.021 \\
\hline Plain ground & 230 & 0.027 & -0.011 & Calluna & 6 & 0.009 & 0.076 \\
\hline Water & 107 & 0.078 & 0.023 & Blackberry & 5 & 0.124 & -0.002 \\
\hline Sunlight & 141 & 0.230 & 0.074 & Ivy & 4 & 0.013 & 0.036 \\
\hline $\mathrm{pH}<5$ & 32 & 0.030 & 0.102 & Peat moss & 18 & 0.022 & 0.071 \\
\hline pH 5-6 & 35 & 0.024 & -0.003 & Hair moss & 5 & 0.183 & 0.008 \\
\hline $\mathrm{pH}>6$ & 32 & -0.052 & -0.069 & Feathermoss & 8 & 0.030 & 0.102 \\
\hline Limestone & 48 & 0.002 & -0.009 & Liverwort & 1 & 0.156 & -0.041 \\
\hline Sand & 20 & -0.062 & -0.009 & Lichens & 4 & 0.082 & 0.140 \\
\hline Pebbles & 23 & 0.057 & -0.004 & Algae & 3 & 0.155 & 0.023 \\
\hline Mull & 57 & -0.121 & -0.036 & Bracken & 21 & 0.014 & 0.044 \\
\hline Moder & 24 & -0.090 & 0.046 & Purple moor grass & 21 & 0.108 & 0.039 \\
\hline Mor & 2 & 0.086 & -0.027 & Hair-grass & 5 & 0.084 & -0.028 \\
\hline Hydromull & 6 & -0.019 & -0.019 & Fescue-like grass & 8 & 0.201 & -0.016 \\
\hline Hydromoder & 3 & -0.030 & 0.004 & Rushes & 6 & 0.219 & -0.013 \\
\hline Hydromor & 3 & -0.017 & 0.021 & Waterlilies & 10 & 0.132 & 0.021 \\
\hline Trunk & 33 & 0.108 & 0.143 & Hawksbeard & 1 & 0.121 & -0.003 \\
\hline Herbs (aerial parts) & 58 & 0.296 & 0.077 & Sedges & 4 & 0.078 & 0.016 \\
\hline Mosses (aerial parts) & 74 & 0.163 & 0.146 & Wood anemone & 20 & -0.037 & 0.045 \\
\hline Superficial soil & 17 & 0.146 & 0.003 & Bluebell & 20 & -0.037 & 0.045 \\
\hline Litter & 80 & 0.213 & 0.068 & Duckweed & 1 & 0.121 & 0.007 \\
\hline Humus & 41 & 0.136 & 0.043 & Mustard & 1 & 0.062 & 0.024 \\
\hline Organo-mineral soil & 18 & -0.049 & -0.032 & Chamomile & 1 & -0.013 & -0.008 \\
\hline Mineral soil & 68 & -0.172 & -0.111 & Chickweed & 9 & 0.053 & -0.078 \\
\hline Mole hill & 4 & 0.028 & -0.007 & Yarrow & 4 & 0.003 & -0.051 \\
\hline Vertebrate dung & 3 & 0.181 & 0.010 & Nettle & 5 & -0.046 & -0.047 \\
\hline Garbage deposits & 11 & -0.045 & 0.058 & Mercury & 16 & 0.036 & 0.022 \\
\hline Wood & 35 & 0.093 & 0.132 & Solomon's seal & 8 & 0.053 & 0.049 \\
\hline Earthworm casts & 7 & -0.036 & -0.013 & Wheat & 7 & -0.011 & -0.051 \\
\hline Tree roots & 5 & 0.067 & 0.053 & Buttercup & 1 & 0.142 & -0.041 \\
\hline Herb roots & 8 & 0.083 & -0.006 & Knotweed & 1 & 0.091 & 0.037 \\
\hline Oak & 142 & -0.048 & 0.015 & Clover & 5 & -0.091 & -0.038 \\
\hline Birch & 41 & 0.113 & 0.026 & Mint & 1 & 0.123 & 0.001 \\
\hline
\end{tabular}


Table 3. Trait attributes of the 128 springtail species collected in the Sénart forest, and number of species where attributes were found

\begin{tabular}{|c|c|c|}
\hline Trait & Attribute & $\begin{array}{c}\text { Number of } \\
\text { species }\end{array}$ \\
\hline \multirow[t]{2}{*}{ Mode of reproduction } & Parthenogenesis dominant & 36 \\
\hline & Sexual reproduction dominant & 89 \\
\hline \multirow[t]{3}{*}{ Body size } & Small & 86 \\
\hline & Medium & 28 \\
\hline & Large & 14 \\
\hline \multirow[t]{3}{*}{ Body form } & Slender & 92 \\
\hline & Stocky & 6 \\
\hline & Spheric & 30 \\
\hline \multirow[t]{3}{*}{ Body color } & Pale-coloured & 60 \\
\hline & Bright-coloured & 30 \\
\hline & Dark-coloured & 38 \\
\hline \multirow[t]{2}{*}{ Scales } & Absent & 109 \\
\hline & Present & 19 \\
\hline \multirow[t]{2}{*}{ Antenna size } & Short & 65 \\
\hline & Long & 63 \\
\hline \multirow[t]{2}{*}{ Leg size } & Short & 61 \\
\hline & Long & 67 \\
\hline \multirow[t]{3}{*}{ Furcula size } & Absent or vestigial & 35 \\
\hline & Short & 25 \\
\hline & Long & 68 \\
\hline \multirow[t]{3}{*}{ Eye number } & 0 & 42 \\
\hline & $1-5$ & 24 \\
\hline & $>5$ & 62 \\
\hline \multirow[t]{2}{*}{ Pseudocella } & Absent & 105 \\
\hline & Present & 23 \\
\hline \multirow[t]{3}{*}{ Post-antennal organ } & Absent & 69 \\
\hline & Simple & 21 \\
\hline & Compound & 38 \\
\hline \multirow[t]{2}{*}{ Trichobothria } & Absent & 72 \\
\hline & Present & 56 \\
\hline
\end{tabular}




\section{Figure legends}

2 Figure 1.Canonical correspondence analysis of species trait attributes: projection of

3

4

5 traits (a) and habitat indicators (b) in the plane of the first two canonical factors F1 and F2. 

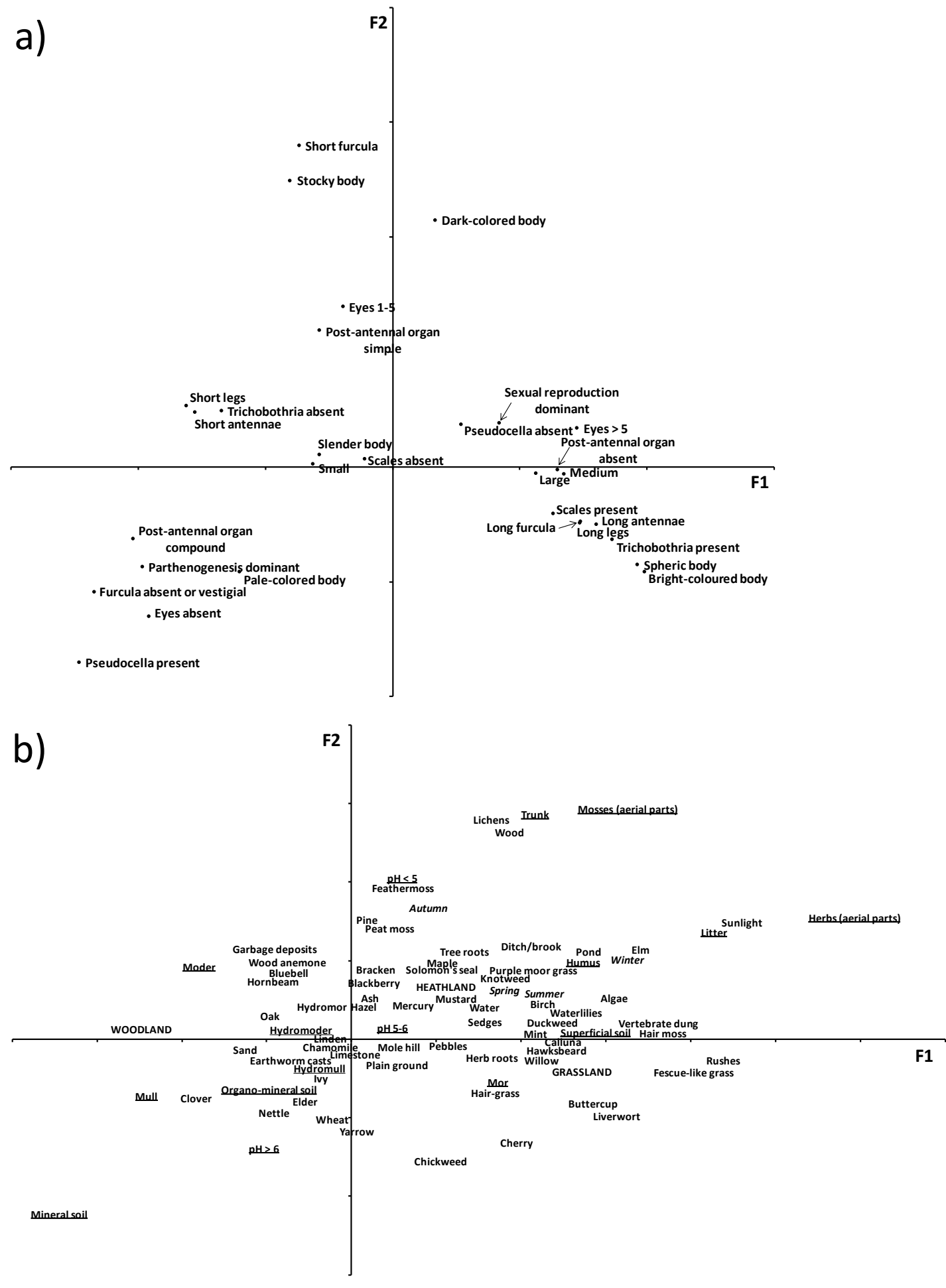

2 Fig. 1 